\title{
Uma recriação mitopoética
}

\section{Tatjana Manojlovic}

\author{
Armando Nascimento Rosa, Um Édipo, Évora, Casa do Sul, \\ 2003, 69 pp.
}

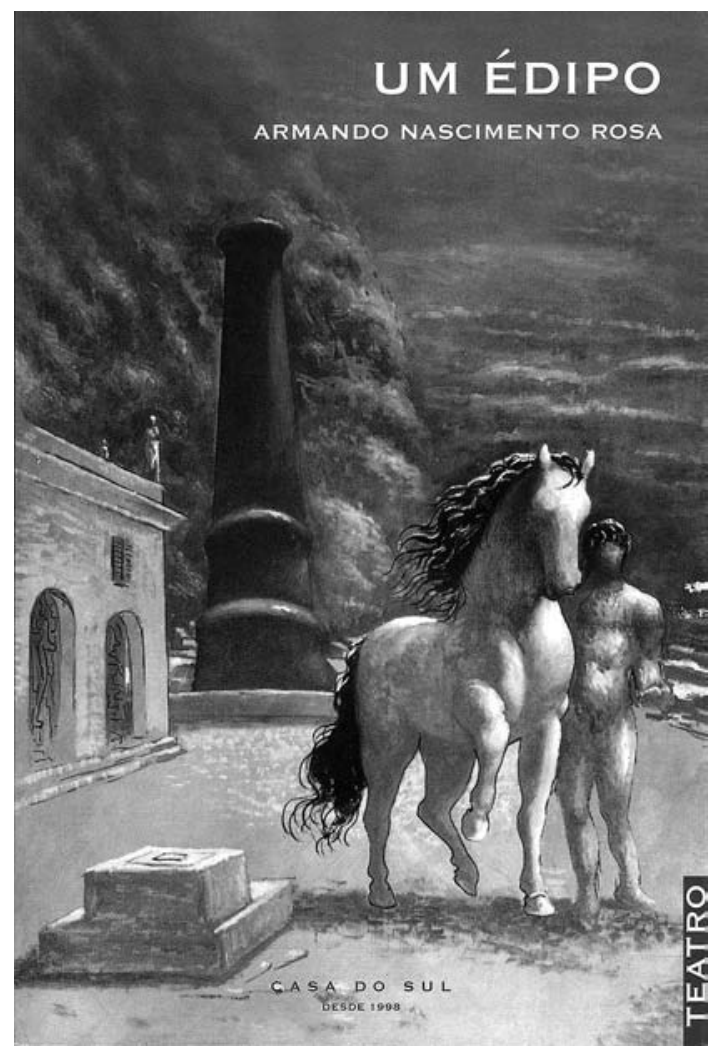

Na história da literatura dramática nacional, encontramos várias recriações baseadas no antigo mito de Édipo: Manuel de Figueiredo escreve OÉdipo, em 1757; Garrett deixa um Édipo em Colono inacabado, do qual apenas restam fragmentos; $e_{1}$ no século $X X$, os dramaturgos influenciados pelo mito tebano são: João de Castro Osório (Trilogia de Édipo, 1955), Natália Correia (O progresso de Édipo, 1957) e Bernardo Santareno (António Marinheiro - Édipo de Alfama, 1960).

A peça Um Édipo, de Armando Nascimento Rosa, estreada no Teatro da Comuna, em Lisboa, em 2003, surge como o primeiro Édipo português no século XXI. Trata-se de um drama que segue o tema presumivelmente abordado nas tragédias perdidas Laio e Édipo, de Ésquilo, e ainda Édipo, de Euripides - o delito de Laio, cuja voluptuosa perversidade e impulso filicídio suscitaram a maldição dos seus descendentes. Na sua mitopoese, Nascimento Rosa reexplora a posição clássica da culpa trágica de Édipo, procurando a origem do crime primordial que provocou a ruína da familia edipiana: "Não são só os filhos que desejam matar e usurpar o trono aos pais. Antes disso, os pais quiseram matar os filhos para que eles não viessem roubar um dia o trono que ocupam" (p. 47), diz Laio, de Nascimento Rosa.

A acção de Um Édipo, designado como "mitodrama fantasmático em um acto", apresenta-se concentrada em três lendas, que tocam, de modos diferentes, o mito principal de Édipo. As primeiras duas lendas são passadas e revisitadas: a da metamorfose de Tirésias e a do primeiro pecado de Laio. A terceira história - a única que vai acontecer-pertence a Manto, a jovem vidente e filha de Tirésias, o mais célebre adivinho da Grécia. Quanto à época mítica na peça portuguesa, o drama distingue-se dos padrões helénico e latino: Rei Édipo, de Sófocles, abre com a peste em Tebas, e Oedipus, de Séneca, começa com o diálogo entre Édipo e Jocasta, assustados ambos pela epidemia na Beócia. Em Nascimento Rosa, a fábula leva-nos até aos tempos de vagueações do cego Édipo e ao último dia da longa vida de Tirésias, a das sete gerações humanas.

A peça abre com a Melodia de Manto, composta pelo Autor, e, no encontro que se segue entre Tirésias e Jocasta, o fantasma ressuscitado da antiga rainha, confrontam-se estes dois tebanos, ambos com suas histórias escondidas. Numa espécie de mútuo jogo psicoterapêutico, Tirésias e Jocasta, cada um atraido pela sensatez e sabedoria do outro, libertam as memórias secretas. 0 espectro de Jocasta consegue alcançar o maior segredo do adivinho - as suas duas transformações do sexo: "Jocasta: Somos todos deuses e demónios, bem o sabes, mas são raros os mortais que conseguem invocar a força sepultada no útero da alma. Tu soubeste fazê-lo, Tirésias. Por isso foste punido. Nunca se sai ileso de um combate cósmico. / Tirésias (demovido pelas palavras dela): A tua lucidez é um bálsamo na minha velhice infinita. A aluna morta ultrapassou o mestre ainda vivo. Fala-me então de mim, para que eu possa lembrar o que já soube e já esqueci ou não recorde mais por culpa da idade e do orgulho"(p. 18). Poderíamos encontrar uma certa semelhança entre as simulações tiresianas do passado, contado por Jocasta, e representações cénicas: em que medida esta "terapia rememorante que aplicam um ao outro" (p. 66), com "o verbo da memória" (p. 25), tem a função de máscara dos seus esquecimentos fingidos? Uma ideia estimulante, que profere Manto - "Os actores são filhos dos xamãs" (p. 33) -, nasce no contexto da sua pretensão, para que Tirésias Ihe deixasse seguir o próprio caminho de actriz. No Posfácio da peça, intitulado "Édipo, reflexo da escrita", o autor refere: "Interessou-me destacar esta analogia entre o mago ancestral que comunica com os espíritos, e 
oferecer-Ihes energia animica para estes se manifestarem, e a tarefa secular do actor, metamorfoseando nas figuras que a dramaturgia solicita" (p. 66). Dai o drama estar repleto de referências ao teatro: "Tirésias: Nada é mais penoso que ver um mortal sem corpo a fingir-se vivo. Não há teatro mais patético no cosmos. Poupa-me ao teu número dramático! 0 meu retiro na ravina não é sítio para palcos de Dioniso"(p. 14). Jocasta fala de Sófocles: "Sei o necessário para que Sófocles se interesse pelo meu testemunho. / Tirésias: Não conheço esse Sófocles, É algum poeta novo de Atenas? / Jocasta: Há-de vir a ser quando nascer um dia e pelas suas palavras havemos tu e eu de habitar na eternidade dos mitos" (p. 16). Tirésias diz a Jocasta: "Muitas actrizes viverão na cena do teu papel; muitos actores hãode esmagar morangos sobre os olhos para fingirem o suplício desse marido que tu deste à luz" (p. 25). Manto fala do seu fascínio pela cena: "0 meu sonho era representar em Atenas. Decorar os papéis de Dioniso e sentir que a possessão do palco é somente uma fábula, uma ficção que ensina, que diverte, e também cura as dores da alma" (p. 33). Tirésias e Jocasta tornam-se espectadores num ofício pitónico de Manto, com o fantasma de Crisipo (p. 41). Ao conduzir Édipo a Hipnos, Manto diz: "Amanhã embarco para Lesbos. (...) 0 meu trono está nas máscaras. É para Lesbos que o futuro me empurra" (p. 52).

0 elenco das sete figuras inclui os vivos Tirésias, Manto e Édipo e os espectros de Jocasta, Crísipo, Pélops e Laio. Na caracterização das personagens que, em busca de identidade ou respostas definitivas aos mistérios esquecidos das suas existências, cruzam os seus caminhos entre o reino de Hades e montes helenos, Nascimento Rosa criou retratos notáveis, entre os quais se destaca Jocasta. Em contraste com a sua homóloga sofocliana - que, num célebre passo, diz a Édipo: "E não vivas no temor das núpcias da tua mãe: é que muitos foram já os mortais que em sonhos a sua mãe se uniram" (1995: 117) -, o espectro da rainha tebana no drama português revela que, antes do incesto, o crime de filicídio já "tinha acontecido": "Também eu não me devia ter separado do meu Édipo em criança. Voltei a juntar-me a ele em adulto sem sabê-lo. E o nosso idílio foi o castigo de o ter enviado para a morte" (p. 23). Ao revisitar o próprio pecado na conversa com Tirésias, Jocasta surpreende-nos com uma visão diferente: "Depois de me enforcar, extinguiu-se agonia e a culpa. Como quando se sai vivo de uma peste mortal, olhamos as coisas com um deslumbramento virgem. Tudo me parece agora tão simples. Os homens amam as mulheres porque desejam mergulhar de novo no mar das delícias que os trouxe para o mundo. (...) 0 amor é um incesto universal. Não valia a pena ter-me enforcado por uma causa tão vulgar como esta" (p. 24).

Com uma outra personagem, também diferente do seu padrão clássico, Manto, a jovem pitonisa, cujo nome invoca a adivinhação, mergulhamos numa bela história inventada, sobre o seu nascimento e a sua evocação cénica. Na mitologia clássica, poucas referências existem em torno de Manto. Nas tragédias que chegaram até nós, a filha de Tirésias aparece como figurante nas Fenícias, de Euripides, e também como a personagem secundária, num único diálogo com o pai, em Édipo, de Séneca. Em Nascimento Rosa, Manto passa a ser a incarnação de paixão pelo teatro. Agarrando-se à ideia do palco, sem realmente conhecer esse desvio novo, Manto torna-se heroína que, pela sua pureza e devoção ao pai cego, bem como pelo apego à vocação escolhida, evoca Antígona. "É uma jovem bem viva a tua filha Manto, essa moça que tanto me faz lembrar a minha Antígona", diz Jocasta (p. 30). Ao despedir-se da vida, Tirésias finalmente liberta a filha: "Jocasta: Ele quer pedir-te uma coisa, mas a sua voz de fantasma ainda é fraca. Sirvo eu de mensageira. / Manto: 0 que é pai? (Tirésias mexe os lábios em silêncio.) Jocasta: Ele diz para saires deste sítio agreste, onde só abutres fazem ninho. Deverás tomar um barco rumo a Lesbos. Nessa ilha poderás cumprir o sonho de actriz. Porque em Lesbos as mulheres sobem ao palco. Vai para Lesbos, Manto, diz teu pai. Guarda os dons de pitonisa e não dês conversa a mortos vagabundos. Dá antes voz aos vivos nos ritos de Dioniso. No palco encontrarás a harmonia" (p. 51). A questão de culpabilidade hereditária, desenvolvida em Um Édipo, ocupa o centro do drama.

Contrastando com o rei tebano das tragédias sofocliana e senequiana, que necessita de Tirésias para decifrar o homicídio de Laio, Édipo, de Nascimento Rosa, já não é rei nem usurpador do trono. Quem está à procura do velho vidente é um homem cego, caminhando para Colono, em busca de respostas definitivas sobre as suas identidade e responsabilidade na história de crimes da tebana prole real. Com tudo isto, ficou claro que estamos perante uma recriação mitopoética, cuja originalidade reside também no facto de ter dado respostas a algumas questões esfíngicas, colocadas no teatro clássico e herdadas no teatro moderno europeu.

0 mundo helénico está constantemente presente no pensamento dramatúrgico de Nascimento Rosa. Um Édipo situa-se cronologicamente entre os dois textos recentes, tematicamente também enquadrados no universo grego mítico/histórico: Nória e Prometeu - Palavras do fogo, o mitodrama paródico, e A última lição de Hipátia, o drama sobre a filósofa e astrónoma alexandrina do séc. V, Hipátia. ${ }^{2}$

Com Um Édipo, digno de ser o primeiro Édipo nacional no século XXI, Armando Nascimento Rosa afirma-se como um dos mais criativos dramaturgos portugueses da actualidade.

\section{Referência bibliográfica}

SÓFOCLES, Rei Édipo, tradução de Maria do Céu Zambujo Fialho, Lisboa Edições 70, 1995.

Nota: Agradeço ao dramaturgo Armando Nascimento Rosa ter-me facilitado a leitura das suas peças ainda inéditas Nória e Prometeu: Palavras do fogo, bem como An Oedipus, a versão inglesa de Um Édipo, e A última lição de Hipátia. 